\title{
LATTUPA: ALAT BANTU KUPAS KELAPA UNTUK MEMPERMUDAH PETANI DAN PEDAGANG KELAPA DALAM MENGUPAS BUAH KELAPA DI KECAMATAN CIKEDUNG KABUPATEN INDRAMAYU
}

\author{
Rahmat Hidayat $^{1}$, Rizki Achmad Darajatun ${ }^{2}$, Supri Handoko ${ }^{3}$ \\ ${ }^{1)}$ Teknik Elektro, Fakultas Teknik, Universitas Singaperbangsa Karawang \\ ${ }^{2,3)}$ Teknik Industri, Fakultas Teknik, Universitas Singaperbangsa Karawang \\ e-mail : rahmat.hidayat@staff.unsika.ac.id
}

\begin{abstract}
Abstrak
Permasalahan umum yang sering terjadi pada petani kelapa dan buruh pengupas kelapa yaitu minimnya alat kupas yang membantu pekerjaan mereka dalam mengupas buah kelapa dengan mudah, cepat, aman, efektif dan efisien. Selain itu, permasalahan khusus yang dialami kelompok mitra adalah (1) Minimnya produk teknologi yang di manfaatkan petani Kelapa dan buruh Kupas (2) rendahnya kemampuan Sumber Daya Manusia (SDM) Petani dan Buruh Kupas terkait dengan bidang teknologi dan manajemen (3) rendahnya kemampuan kelompok sasaran dalam pemanfaatan teknologi pertanian alat kupas buah Kelapa sebagai sarana meningkatkan hasil pertanian buah Kelapa. Solusi dalam program ini adalah (1) pemanfaatan produk teknologi untuk masyarakat Petani Kelapa dan Buruh Kupas di Kecamatan Cikedung Indramayu, (2) Pelatihan penggunaan teknologi, perawatan dan pembuatan melaui program produk teknologi yang di desiminasikan ke masyarakat (3) peningkatan kemampuan SDM Petani dan Buruh dalam bidang teknologi. Produk teknologi yang di desiminasikan ke masyarakat yang telah dilakukan adalah memproduksi alat bantu kupas kelapa (LATTUPA), diklat penggunaan LATTUPA, penerapan teknologi LATTUPA dan serah terima LATTUPA kepada mitra kegiatan. Hasil yang didapat kelompok sasaran atau mitra dari program ini dapat disimpulkan bahwa warga khususnya petani atau buruh pengupas kelapa dapat mengetahui pemanfaatan alat bantu kupas kelapa (LATTUPA) dengan baik, juga warga khususnya buruh pengupas kelapa dapat mengetahui berbagai macam bagian dan manfaatnya. Alat kupas ini menurut warga berdampak pada peningkatan kesejahteraan serta ekonomi.
\end{abstract}

Kata Kunci: Cikedung, Kelapa, Petani, Buruh Kupas, Pertanian

\begin{abstract}
A common problem that often occurs with coconut farmers and coconut peeling workers is the lack of peeling tools that help their work in peeling coconuts easily, quickly, safely, effectively and efficiently. In addition, specific problems experienced by partner groups are (1) The lack of technology products that are utilized by coconut farmers and Peel laborers (2) low ability of Human Resources (HR) Farmers and Peeled Laborers related to technology and management (3) low ability target groups in the use of agricultural technology Coconut peel tools as a means of increasing agricultural output of the Coconut fruit. The solutions in this program are (1) the use of technology products for the community of Coconut Farmers and Peeled Workers in the District of Cikpapan Indramayu, (2) Training in the use of technology, maintenance and manufacturing through technology product programs that are disseminated to the community (3) enhancing the capabilities of Farmers' HR and Labor in technology. Technology products disseminated to the public that have been carried out are producing coconut peel aids (LATTUPA), training for the use of LATTUPA, applying LATTUPA technology and handover of LATTUPA to partner activities. The results obtained by the target group or partners from this program can be concluded that the residents, especially farmers or coconut peeling workers can know the utilization of coconut peel tools (LATTUPA) well, also residents especially coconut peeling workers can know various types and their benefits. This peel tool according to the residents has an impact on improving welfare and the economy.
\end{abstract}

Keywords: Cikedung, Coconut, Farmers, Peeled Laborers, Agriculture 


\section{PENDAHULUAN}

Mitra dalam program ini adalah 1) Gabungan Kelompok Tani Mulus (Gapoktan Mulus) Desa Mundakjaya, Kecamatan Cikedung, Kabupaten Indramayu, 2) Ketua Kelompok Mekartani 01 (Satu), 3) Kepala Desa Mundakjaya Kecamatan Cikedung, Kabupaten Indramayu. Gabungan kelompok tani (gapoktan) yang sebagian besar adalah laki-laki. Seperti yang kita ketahui Indramayu merupakan salah satu daerah yang terkenal akan pertaniannya. Selain pertanian Padi, di Indramayu juga ada Pertanian serta Perkebunan Buah Kelapa. Pertanian buah Kelapa di Indramayu mampu memasok kebutuhan konsumsi buah Kelapa daerah. Selain itu, di Indramayu juga banyak pedagang buah kelapa yang berjualan buah kelapa serta penduduknya banyak sebagai buruh pengupas kelapa. Untuk mendukung program swasembada pangan khususnya Buah Kelapa maka dibutuhkan teknologi mekanisasi dan modernisasi peralatan produksi maupun pasca panen. Mengingat kondisi pertanian sekarang masih banyak yang menggunakan teknologi konvensional dalam bidang pertanian Kelapa, selain itu permasalahan dari sisi penggunaan teknologi pertanian juga masih banyak yang belum memanfaatkan teknologi sebagai alat bantu.

Cikedung adalah salah satu kecamatan yang terletak di Kabupaten Indramayu dengan luas area $70,84 \mathrm{~km}^{2}$. Kecamatan Cikedung berbatasan dengan kecamatan losarang di utara, Kabupaten Majalengka di selatan, Kecamatan Terisi di barat dan Kecamatan Lelea di timur. Kecamatan Cikedung terdiri dari delapan desa yaitu; (1) Cikedung Kidul; (2) Loyang; (3) Amis; (4) Cikedung Lor; (5) Cikedung; (6) Jambak; dan (7) Jatisura;. Desa Cikedung Kidul merupakan ibukota Kecamatan Cikedung yang memiliki luas $378 \mathrm{Ha}$, dengan jumlah padat penduduk sebesar 4.204 jiwa (BPS, 2017:51).

Seperti yang kita ketahui bahwa buah kelapa kelapa bertebaran di wilayah Indramayu dan sekitarnya merupakan potensi yang besar, bahkan banyak orang yang menekuni bidang yang berkaitan dengan kelapa. Sebagai contoh pemetik kelapa, penjual kelapa, penebang buah kelapa kelapa, buruh pengupas kelapa dan lain-lain. Buah kelapa kelapa merupakan tumbuhan yang kaya akan manfaat, semua bagian dari kelapa bisa dimanfaatkan. Diantaranya air dan daging buah kelapa banyak digunakan untuk minuman segar yang dijual di pedagang es yang ada dipinggirpinggir jalan, bahkan juga merupakan menu andalan dari hotel-hotel berbintang. Tempurung buah kelapa yang digunakan untuk bahan dasar pembuatan arang dan juga bisa digunakan untuk bahan bakar. Sabut buah kelapa bisa digunakan untuk kerajinan tangan, sapu, bahan bakar, media tanam dan lain-lain. Batang buah kelapa kelapa bisa digunakan untuk bahan baku bangunan, kerajinan, gagang aneka alat pertanian dan lain-lain. Daun kelapa bisa juga digunakan sebagai pembungkus makanan dan sedangkan lidinya dapat digunakan untuk membuat sapu sebagai alat pembersih halaman. Semua bagian dari buah kelapa kelapa bisa dimanfaatkan.

Dapat kita ketahui bahwa pengembangbiakan buah kelapa kelapa ini terbilang cukup mudah, yaitu hanya dengan menanam buah kelapa yang sudah tua dan kering. Di wilayah Pulau Jawa khususnya Indramayu hampir setiap rumah memiliki beberapa buah kelapa kelapa yang dimanfaatkan secara aktif untuk diambil kelapa mudanya, kelapa tuanya bahkan pada waktu-waktu tertentu diambil daunnya untuk pembungkus makanan. Pemeliharaan buah kelapa kelapa juga tidak terlalu susah tinggal tanam kemudian siram air secukupnya. Setelah buah kelapa kelapa tumbuh subur dan akhirnya mengghasilkan buah tibalah saat pemanenan, setelah buah kelapa dipanen tiba saatnya proses produksi setelah panen, proses produksi dilakukan dengan tujuan untuk membuat buah kelapa bisa menjadi komoditas yang dapat dan siap dijual ataupun bisa menjadikan lebih tinggi nilai ekonomisnya di masyarakat. Tentunya sebelum proses produksi berlangsung, ada beberapa proses atau tahapan yang membutuhkan waktu cukup lama, tahapan-tahapan tersebut adalah: pemetikan buah kelapa yang sudah tua, pemisahan sabut kelapa dan tempurung kelapa, pemisahan daging dan air kelapa dengan tempurung, dan pengupasan kulit ari daging buah kelapa. Dan semua proses atau tahapan tersebut tidaklah mudah dan tentu juga melelahkan serta membutuhkan banyak waktu dan biaya.

Berdasarkan pada uraian diatas maka pada program produk teknologi yang di desiminasikan ke Masyarakat ini akan mendesiminasikan alat tentang teknologi pengupasan sabut kelapa, yang hingga saat ini masih dilakukan secara manual di kalangan usaha menengah kebawah, dan proses tersebut juga membutuhkan waktu yang cukup lama, membutuhkan banyak tenaga, juga resiko/berbahaya karena biasanya menggunakan besi tajam yang ditancapkan ditanah, dan bagian runcing atau tajamnya di bagian atas dan orang yang mengupas sabut kelapa posisi badan dan 
tangannya berada diatas besi tajam tersebut sehingga resiko cidera/terluka karena alat akan menjadi lebih besar.

Beberapa sektor mengalami beberapa permasalahan seperti pada proses pengupasan sabut kelapa dimana sering kali terjadi kendala atau pun cidera ketika mengupas sabut kelapa. Dengan mengamati dan mempraktikkan sulitnya mengupas sabut kelapa secara konvensional maka penulis muncul keinginan untuk mendesiminasikan produk teknologi LATTUPA: Alat Bantu Kupas Kelapa yang telah dibuat ke Masyarakat mitra yang dapat mempermudah melakukan proses pengupasan sabut kelapa. Dengan adanya alat yang dibuat diharapkan proses mengupas sabut kelapa menjadi lebih mudah dan lebih aman. Permasalahan dari sisi penggunaan teknologi dalam pengupasan sabut kelapa juga masih banyak Buruh pengupas kelapa, Petani dan Pedagang Kelapa serta Masyarakat Desa Mundakjaya dan Cikedung Lor yang belum memanfaatkan teknologi modern sebagai alat bantu.

Program produk teknologi yang di desiminasikan ke Masyarakat ini dimaksudkan untuk memberikan pemahaman, pelatihan,pengguanaan dan perawatan produk teknologi kepada kelompok Petani, Buruh Pengupas Kelapa dan Pedagang Kelapa serta Masyarakat di Desa Mundakjaya dan Cikedung Lor, Kecamatan Cikedung Kab. Indramayu yang memiliki potensi pertanian padi, dan perkebunan Kelapa dan Pedagang Kelapa serta Buruh Pengupas Kelapa yang sangat besar di wilayah ini. Sebagian besar Masyarakat Desa Mundakjaya dan Cikedung Lor, Cikedung Indramayu belum mengetahui kalau teknologi itu penting untuk membantu dan meringankan pekerjaan Buruh Pengupas Kelapa, Petani dan Pedagang Kelapa serta Masyarakat, oleh karena itu diperlukan Program produk teknologi yang di desiminasikan ke Masyarakat berupa LATTUPA (Alat Bantu Kupas Kelapa).

Berikut adalah beberapa potret kehidupan Buruh Pengupas Kelapa, Pedagang Kelapa, dan Petani kelapa serta Masyarakat di Cikedung,Indramayu, Jawa Barat:

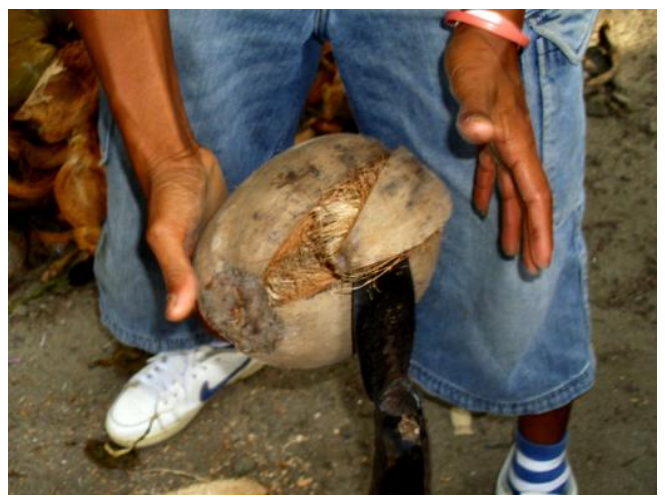

Gambar 1. Mengupas kelapa dengan Linggis(Manual)

Dengan mengamati hal di atas dan survey maka munculah suatu ide untuk mendesiminasikan produk teknologi LATTUPA (Alat Bantu Kupas Kelapa) agar dapat meringankan beban pengupasan kelapa Petani Kelapa, Buruh Pengupas Kelapa dan Pedagang Kelapa serta Masyarakat di Desa Mundakjaya dan Cikedung Lor, Kecamatan Cikedung pada khususnya dan di Indramayu, Jawa Barat pada umumnya.

\section{METODE}

Metode pelaksanaan pengabdian yang telah dilakukan adalah sebagai berikut.

1. Sosialisasi produk teknologi yang di desiminasikan ke masyarakat pengupas buah kelapa kelapa, gabungan kelompok tani, pemerintah desa dan kecamatan Cikedung Kabupaten Indramayu

2. Menerapkan,mendemokan, penyerahan LATTUPA dan mengaplikasikan alat bantu kupas kelapa (LATTUPA) kepada pengupas buah kelapa kelapa, gabungan kelompok tani, pemerintah desa kecamatan Cikedung Kabupaten Indramayu

3. Penyerahan alat bantu kupas kelapa (LATTUPA) yang telah di buat sebanyak 20 buah alat pengupas kelapa kepada gabungan kelompok tani, Buruh Pengupas Kelapa dan Pedagang 
Kelapa, Masyarakat, dan pemerintah desa Desa Mundakjaya dan Cikedung Lor di Kecamatan Cikedung Kabupaten Indramayu

4. Evaluasi produk teknologi yang di desiminasikan ke masyarakat tentang alat bantu kupas kelapa (LATTUPA), evaluasi meliputi 1). Kehandalan alat, 2). kekuatan alat bantu kupas kelapa, dan 3). Efektifitas alat bantu kupas kelapa (LATTUPA)

Evaluasi dilakukan setiap 2 bulan sekali selama program dan setelah program produk teknologi yang di desiminasikan ke masyarakat.

\section{HASIL DAN PEMBAHASAN}

Hasil pengabdian terdiri dari Program Produk Teknologi yang di Desiminasikan ke Masyarakat (PTDM) berupa Luaran yang dicapai atau output dari produk teknologi yang di desiminasikan ke masyarakat ini berupa alat bantu kupas kelapa (LATTUPA) yang diterapkan di gabungan kelompok tani (gapoktan), buruh pengupas kelapa yang diwakili oleh perwakilan pengupas buah kelapa kelapa, ketua BUMDes, Kepala Desa Mundakjaya dan pihak Kecamatan Cikedung, Kabupaten Indramayu, Jawa Barat adalah sebagai berikut:

1. Adanya Edukasi Teknologi bagi masyarakat mitra yang mengedepankan Sikap Pro-Kesahatan dan Pro-Lingkungan bagi petani, Masyarakat, Buruh Pengupas Kelapa dan Pedagang Kelapa.

2. Dengan adanya program produk teknologi yang di desiminasikan ke masyarakat ini maka kelompok sasaran atau mitra mempunyai pengetahuan, keahlian serta mampu memanfaatkan produk teknologi LATTUPA (alat bantu kupas kelapa) yang bisa dipakai untuk petani, buruh dan masyarakat dalam hal mengupas buah kelapa kelapa.

3. Adanya kolaborasi antara masyarakat Desa Mundakjaya dan Cikedung Lor, Kecamatan Cikedung, Kab. Indramayu dengan Peneliti/Dosen Universitas Singaperbangsa Karawang

4. dalam pengembangan dan penerapan teknologi LATTUPA (alat bantu kupas kelapa) yang bisa membantu masyarakat sekitar

5. Adanya pemahaman produk teknologi LATTUPA (alat bantu kupas kelapa) melalui Pelatihan penggunaan, dan perawatan produk LATTUPA (alat bantu kupas kelapa)

6. Adanya pelaksanaan produk teknologi yang di desiminasikan ke masyarakat LATTUPA (Alat bantu kupas kelapa) ini ternyata dapat meningkatkan Skill teknologi dan semakin memperkuat usaha tani, Pedagang Kelapa, dan buruh pengupas kelapa yang selama ini telah menjadi bidang usahanya.

7. Setelah pelatihan program produk teknologi yang di desiminasikan ke masyarakat melalui adanya LATTUPA (Alat bantu kupas kelapa) maka ada kegiatan Penyerahan alat bantu kupas kelapa (LATTUPA) yang telah di buat sebanyak 20 buah alat ke petani kelapa, masyarakat, dan buruh di kecamatan Cikedung Kabupaten Indramayu

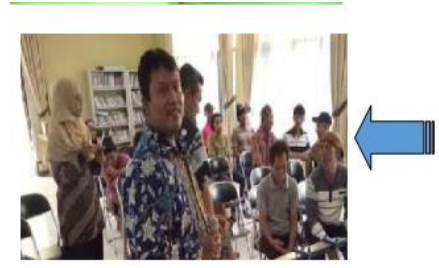

Sosialisasi Fungsi,

Penggunaan dan

Perawatan Alat

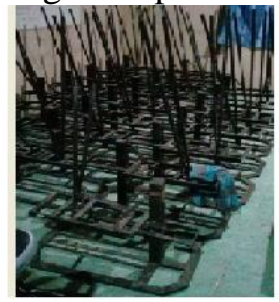

Packing LATTUPA

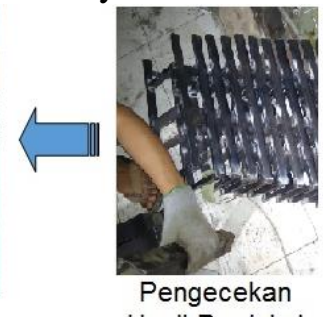

Hasil Produks

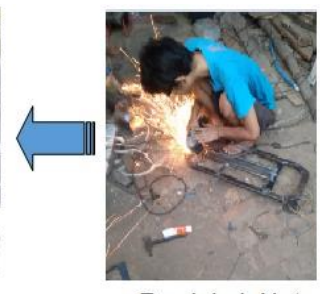

Produksi Alat

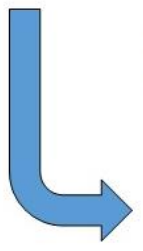

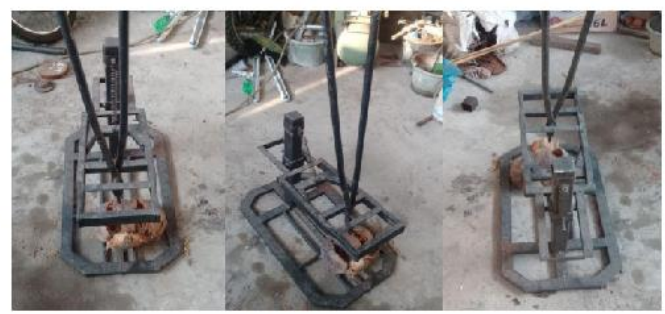

Penerapan Alat Bantu Kupas Kelapa (LATTUPA)

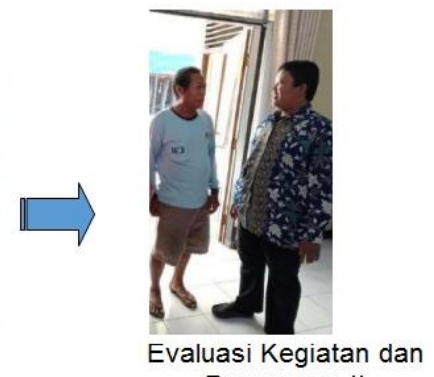

Penerapan II

Gambar 2. Proses Kegiatan Pengabdian Kepada Msyarakat LATTUPA 


\section{Fungsi dan Manfaat Produk Teknologi}

Fungsi dan manfaat produk teknologi yang di desiminasikan ke masyarakat ini penting untuk petani, masyarakat dan buruh. Adapun fungsi dan manfaat produk teknologi ini adalah sebagai betikut.

1. Alat bantu kupas kelapa (LATTUPA) dapat digunakan sebagai sarana alat bantu kupas kelapa bagi petani dan pedagang kelapa dalam mengupas hasil panen berupa buah kelapa. Alat ini pro-lingkungan dan pro-kesehatan

2. Alat bantu kupas kelapa (LATTUPA) dapat digunakan sebagai sarana alat kupas buah kelapa untuk melakukan aktivitas dalam mengupas buah kelapa

3. Alat bantu kupas kelapa (LATTUPA) dapat digunakan sebagai sarana penunjang dan sebagai "icon" Petani dan buruh pengupas kelapa di Kecamatan Cikedung Indramayu, Jawa Barat.

4. Manfaat produk teknologi yang di desiminasikan ke masyarakat ini diharapkan kelompok sasaran atau mitra mempunyai pengetahuan, keahlian serta mampu memanfaatkan produk teknologi LATTUPA (alat panajat buah kelapa kelapa) sehingga dapat membantu dan meringankan pekerjaan petani dan buruh serta dapat meningkatkan pendapatan para petani dan buruh.

5. Dengan adanya peningkatan pendapatan ini maka akan miningkat pula taraf hidup dan pendidikan masyarakat di desa Mundakjaya dan Cikedung Lor, Kecamatan Cikedung, Indramayu, Jawa Barat.

\section{Dampak Ekonomi dan Sosial}

Dampak Ekonomi dan sosial yang terjadi setelah melakukan program produk teknologi yang di desiminasikan ke masyarakat dan penyerahan produk teknologi alat bantu kupas kelapa (LATTUPA) sebanyak 20 buah di desa Mundakjaya dan Cikedung Lor, Kecamatan Cikedung, Indramayu, Jawa Barat ini adalah adanya respon dan tanggapan yang baik dari petani dan buruh karena LATTUPA yakin dan mampu membantu pekerjaan petani dan buruh pengupas kelapa. Selain dapat membantu dan meringankan pekerjaan petani dan buruh serta dapat meningkatkan pendapatan para petani dan buruh pengupas kelapa. Dengan adanya peningkatan pendapatan ini maka akan miningkat pula taraf hidup dan pendidikan masyarakat di desa Mundakjaya dan Cikedung Lor, Kecamatan Cikedung Indramayu, Jawa Barat.

Selain itu dampak sosial yang terjadi setelah melakukan program produk teknologi yang di desiminasikan ke masyarakat dan penyerahan produk teknologi alat bantu kupas buah kelapa kelapa (LATTUPA) sebanyak 20 buah di Kecamatan Cikedung Indramayu, Jawa Barat ini adalah tumbuhnya jiwa gotong royong atau kekompakan diantara gabungan kelompok tani (gapoktan), buruh pengupas kelapa, BUMDes, pemerintah desa dan kecamatan yang disatukan melalui program ini.

\section{Kontribusi Terhadap Sektor Lain}

Dari Hasil pelaksanaan produk teknologi yang di desiminasikan ke masyarakat yaitu mendesiminasikan alat bantu kupas kelapa di Kecamatan Cikedung Indramayu, Jawa Barat ini ternyata mampu memberikan kontribusi terhadap sektor lain misalnya, pertanian, kesehatan, Technopreneurship, dan Manajemen teknologi. Dibidang Pertanian, LATTUPA mampu memberikan kontribusi positif yaitu mengupas hasil pertanian berupa mengupas buah kelapa secara aman, nyaman efektif dan efisien.

Selanjutnya, alat bantu kupas kelapa (LATTUPA) memberikan kontribusi dibidang kesehatan pada petani dan buruh pengupas kelapa di Cikedung Indramayu karena mereka mengandalkan alat bantu kupas kelapa (LATTUPA) untuk mengupas dan meringankan otot tangan, kaki dan badan dalam mengupas buah kelapa. Petani dan buruh yang mengupas kelapa tanpa adanya alat kupas kelapa (LATTUPA) maka akan terasa berat dan butuh waktu yang lama dalam mengupas buah kelapa dan lama kelamaan bisa mengakibatkan kelelahan bahkan cidera pada tangan, otot-otot tangan dan otot-otot kaki.

Selain itu, alat bantu kupas kelapa (LATTUPA) memberikan kontribusi juga dibidang Manajemen teknologi. Hal ini bisa dilihat dari kemampuan pemanfaatan produk teknologi tepat guna kelompok sasaran atau mitra meningkat $80 \%$ dalam bidang bidang pertanian dan buruh 
dalam mengupas buah kelapa kelapa. Selanjutnya Petani, pedagang buah kelapa dan buruh di Cikedung Indramayu juga meningkat dalam Kemampuan Sumber Daya Manausia (SDM) kelompok sasaran atau mitra meningkat $70 \%$ dalam bidang manajemen teknologi. Selain itu, kemampuan kelompok sasaran juga meningkat $60 \%$ dalam perawatan alat bantu kupas kelapa (LATTUPA).

\section{SIMPULAN}

Dari kegiatan produk teknologi yang di desiminasikan ke masyarakat ini tentang LATTUPA: Alat bantu kupas kelapa untuk Mempermudah Petani Kelapa dalam Mengupas Buah Kelapa, dapat disimpulkan bahwa:

Masyarakat khususnya petani dapat mengetahui dengan baik pemanfaatan dan perawatan LATTUPA: Alat bantu kupas kelapa untuk memudahkan pekerjaan Petani dan Buruh di Kecamatan Cikedung Kabupaten Indramayu,

Selain itu, buruh kupas buah kelapa dan pedagang kelapa dapat mengetahui cara atau memposisikan dan perawatan LATTUPA yang baik dan menempatkan alat di beberapa pengaturan untuk mengupas buah kelapa dan Perlu kegiatan evaluasi lanjutan tentang optimalisasi pemanfaatan teknologi pertanian dan alat kupas kelapa untuk masyarakat petani dan buruh.

\section{SARAN}

1. Dalam pengerjaan program produk teknologi yang di desiminasikan ke masyarakat ini tentang LATTUPA dilakukan dengan membuat tim inti di lokasi dan perlu dukungan berbagai pihak untuk pengaplikasian LATTUPA

2. Dalam Program ini harus memberdayakan masyarakat sekitar dalam proses pengaplikasian dan evaluasinya

\section{UCAPAN TERIMA KASIH}

Terimakasih atas dukungan pendanaan Program produk teknologi yang di desiminasikan ke masyarakat Tahun 2019, Direktur Riset dan Pengabdian Masyarakat, Direktorat Jendral Penguatan Riset dan Pengembangan Kementrian Riset, Teknologi, dan Pendidikan Tinggi Sesuai dengan Perjanjian Penugasan Pelaksanaan Program produk teknologi yang di desiminasikan ke masyarakat Nomor: 170/ SP2H/PPM/DPRM/2019, Tanggal 5 Juli 2019.

\section{DAFTAR PUSTAKA}

Badan Pusat Statistik (BPS) Kabupaten Indramayu. 2017. Kabupaten Indramayu dalam Angka. Indramayu: BPS Kabupaten Indramayu.

Pemerintah Daerah Kabupaten Indramayu. 2015. Profil Kecamatan Cikedung. Indramayu: Pemda Kabupaten Indramayu.

Suherman Eman. 2008. Desain Pembelajaran Kewirausahaan. Bandung: Alfabeta Bandung. 